\title{
Test of Weak Form Efficiency and Nigerian Foreign Exchange Market Volatility
}

\author{
Ejem, Chukwu Agwu ${ }^{1}$ Ogbonna, Udochukwu Godfrey ${ }^{2}$ \\ 1.Department of Banking and Finance, Abia State University, Uturu,Nigeria \\ 2. Department of Management Science, Rhema University, Aba, Nigeria
}

\begin{abstract}
Beside the stated concerns for this study, a lot of scholarly articles abound on the test of weak form efficiency and capital market. For that, the researchers deemed it fit to test if the Nigerian foreign exchange market follows a random walk or not. This and others led to this study, test of weak form efficiency and volatility of the Nigerian foreign exchange market with the following parametric tools; Augumented Dickey Fuller (ADF) unit root test, Pairwise Granger Causality test, Regression test, Normality/Random Walk test, ARCH-GARCH Model, the Autocorrelation cum partial autocorrelation method and Variance Ratio Test. After the analysis, all the results confirmed that the Nigerian foreign exchange market does not follow a random walk, hence weak form inefficient. No wonder the exchange rate business in Nigeria is very lucrative. The dealers always make abnormal profit at every slightest opportunity. Again, the result of the EGARCH framework found that volatility exacts negative impact on Nigerian foreign exchange market and that exchange rate volatility in Nigerian foreign exchange market is persistent. Again, that there is no asymmetric effect in the Nigerian foreign exchange market. Consequent upon the findings, the researchers suggest that the regulatory authorities of the Nigerian foreign exchange market tighten up their belt to enhancing the efficiency of the market. Again, the authority must do everything to stabilize the naira to ensure efficiency in the foreign market in Nigeria.
\end{abstract}

Keywords: Weak form, Foreign Exchange Market, Parametric tool, Nigeria

DOI: $10.7176 /$ RJFA/11-16-14

Publication date:August $31^{\text {st }} 2020$

\section{Introduction}

The foreign exchange market is seen as the market in which individuals, firms and banks purchase and sell foreign currencies or foreign exchange. It is the mechanism, institutional arrangement through which foreign currencies, futures and options are traded. Unarguably, the main function of the foreign exchange markets is the transfer of funds or purchasing power from one nation and currency to another. The market offers facilities for determination of realistic exchange rate among currencies of different nations in a bid to assist the flow mechanism of such currencies among participants of concerned nations, alongside settlement of international account. This is usually aided by electronic fund transfer media. Before now, it was mainly accomplished by a telegraphic transfer, which is a cheque that is wired rather than mailed. With these, a domestic bank instructs its correspondent bank in a foreign monetary centre to pay a specified amount of the local currency to a person, firm or account. The innovations like direct dialing telephone or electronic mail services anywhere in the world, the telex has become relatively less important (Salvatore, 2004; Ezirim, 2005).

The rate of exchange in the foreign exchange market is determined by the quantity of a local currency (say Nigerian Naira) that is required to purchase a foreign currency (say United State America (USA) Dollar). In market driven economy, it is determined by the forces of demand and supply. Both the buyer and seller will always agree to sell at the rate which clears the market for foreign exchange, that is the equilibrium rate (the rate the demand for foreign currency equals the supply of foreign currency). However, if a nation's total demand for foreign exchange in the course of foreign transactions exceeds its total foreign exchange earnings, the rate at which currencies exchange for one another will have to change to equilibrate the total quantities demanded and supplied. If such adjustment in the exchange rates were not permitted, the nation's commercial banks would have to borrow from the nation's central bank. The Central Bank of Nigeria (CBN) for instance would then act as the lender of last resort and draw down its foreign exchange reserve (a balance of payment deficit for the reporting nation). Conversely, if the nation generated an excess supply of foreign exchange in the course of its business transactions with other nations and the adjustment in exchange rates were disallowed; the excess supply would be exchanged for the national currency at the nation's central bank, thereby increasing the nation's foreign currency reserves (a balance of payment surplus for the reporting nation) (Salvatore, 2004; Ejem and Jombo, 2011).

On the relationship between the foreign exchange market and weak form hypothesis of efficient market hypothesis (EMH), the Weak Form and Random Walk EMH which is the oldest statement of the hypothesis holds that present stock prices reflect all known information with respect to past stock prices, trends and volumes. This is also applicable in the foreign exchange market. This is because an efficient exchange rate market is the one that fully utilizes all available information implying there is no unexploited information. 
Furthermore, all participants in the foreign exchange market make use of all available information to provide a set of exchange rates both spot and forward that do not provide any opportunity for unusual profits. Speculators in the market have no room to make abnormal profits. There is no room for government intervention in the foreign exchange market because it reflects all available information (Mabakeng and Sheefeni, 2014). The weak form of the EMH is summed up in the words of the pseudonymous 'Adam Smith', author of the Money Came: 'Prices have no memory, and yesterday has nothing to do with tomorrow' (Broyle, 2003; Brealey and Myers, 2003; Bhalla, 2011). A foreign exchange market is said to be weak form efficient or satisfy weak form efficiency if it fully incorporates the information in the past exchange rates. Thus the preceding strategy would not be able to generate profit if weak form efficiency holds (Ross, Westerfield, Jaffe and Jordan, 2009). Downey and Scott (2020) maintained that the efficient market hypothesis (EMH), alternatively known as the efficient market theory, is a hypothesis that states that share prices reflect all information and consistent alpha generation is impossible.

On volatility, it is a phenomenon that depicts changeableness of variables under consideration and one of the most important concepts in finance. In this context, there are two features of exchange rate volatility; volatility persistence and asymmetric effect. The volatility persistence entails volatility shocks having long memory and its effect lasting for many periods. Simply put, it has to do with how long it will take volatility to revert to its long run average or die out. While asymmetric effect on the other hand is the tendency for bad news (negative news) and good news (positive news) of equal magnitude to producing different impacts on volatility. However, if bad news induces volatility more than good news of equal size or magnitude, at this scenario, asymmetric effect is seen to be leverage effect (Black, 1976; Brooks, 2008; Emenike and Aleke, 2012; Okpara, 2012). The issue of exchange rate volatility is an indispensable issue for policy makers, importers and exporters in international financial markets. Firms use volatility models in their daily estimations of risks and as a gauge when evaluating prices. The policy makers on their own make use of information about how the factors influence the exchange rate volatility so that the most appropriate policy can be conducted (Bauwens and Sucarat, 2005; Backman, 2006; Becmann, 2013). In support of the volatile nature of exchange rate, Husted and Melvin (1993) revealed overshooting exchange rates with emphasis that; it is possible that the exchange rate may not always move in such orderly fashion to the new long run equilibrium after a disturbance (Backman, 2006). At time it appears that spot exchange rates move too much given some economic disturbances. It is observed in most cases when country say Nigeria has a higher inflation rate than country say Ghana, yet Nigeria currency appreciates relative to Ghana's (Ugwuja, 2017). Such anomalies is explained under the context of an 'over shooting' exchange rate model. It is assumed that financial markets adjust instantaneously to an exogenous shock, whereas goods markets adjust slowly over time (Becmann, 2013). Knowing fully that, purchasing power parity does not hold well under flexible exchange rates and that exchange rates exhibit much more volatile behavior than prices. It is expected that in the short run, following some disturbance to equilibrium level, prices will adjust slowly to new equilibrium level, whereas interest and exchange rate will adjust quickly (Ugwuja, 2017). This different speed of adjustment to equilibrium allows for some interesting behavior regarding exchange rates and prices (Ugwuja, 2017).

The encounter of Pukthuanthan-Le and Thomas (2008) assertion that, 'for many technical trader, the basic idea is trend is your friend. That means traders believe exchange rates exhibit inertia in such a way that a positive move in one period is likely to be followed by a positive move in subsequent period'. Surprisingly, academic test of weak form in foreign exchange market efficiency have supported the technical traders. Many also assume that the exchange volatility is constant. These aroused the researchers interest to examine if the same trend in Nigerian foreign exchange market toe the same line of the assertion of Pukthuanthan-Le and Thomas (2008), hence the study; Test Of Weak Form Efficiency And Nigerian Foreign Exchange Market Volatility. The remaining sections of this study are arranged as follows. Section 2 reviews some theoretical and empirical literature related to this study, section 3 describes the data and methodology, section 4 analyzes and discusses the findings of this study, and finally section 5 concludes and recommends for policy making.

\section{Literature Review}

\subsection{Theoretical Literature Review}

In finance and economics, plethora of researches dwelt on stock prices and the efficient market hypothesis $(\mathrm{EMH})$, which actually was the foundation of the proponent of the theories, but the basis of the theory; efficient market hypothesis (EMH) can be lent to other dynamic field like the foreign exchange rates. The random walk hypothesis was first formalized by a French mathematician Bachelier (1900) who presented convincing evidence that commodity speculation in France was a "fair game" meaning that neither buyers nor sellers could expect to make profit. The induction for random walk hypothesis is a variation on the economists classical efficiency argument which holds that $\$ 100$ bill will never be found lying on the sidewalk because someone else would have packed it up first. This intuition incited study on the issue and for the past century it has been exhaustively debated upon (Okpara 2011). Pearson (1905) became perplexed by the problem of the random walk and after 
making some analytical observations appealed to the readers of nature for a solution as the problem was of considerable interest to him. The random walk also known as the drunkards walk is central to probability theory and still occupies the quantitative mind today. Rayleigh (1905) responded to the appeal of Pearson and his contributions led Pearson to conclude that "the most probable place to find a drunkard who is at all capable of keeping on his feet is somewhere near his starting point.

Applying the random walk theory to finance and precisely stock market, it is contended that stock prices take a random and unpredictable path. The chance of a stock future price going up is the same as its going down implying that stock prices change randomly, thus making it impossible to be predicted. In the words of Fama (1965) successive price changes in individual securities are independent depicting that the past history of the series cannot be used to predict the future in any meaningful way. Fama (1970) categorized three types of efficient markets as weak-form, semi-strong and strong form efficiency. The weak form covers all past information concerning prices and returns; the semi-strong form covers all publicly available information while the strong form covers all information be it private and public. The strong form of the efficient market hypothesis states that current market price instantaneously and fully reflects all pertinent information including everything that is known whether it is public or private so that no group of investors has a monopolistic access to any information that could be usurped to beat the market Malkiel (1973). Wickremasinghe (2004) asserted that the last form of efficiency comprise of both the weak and semi-strong forms of the EMH

\section{The Asset Approach model}

This modern theory places emphasis on the role of exchange rate as one many prices in the global market for financial assets. The modern exchange rate theory laid emphasis on finance-asset markets. Rather than the traditional view of exchange rates adjusting to equilibrate international trade in goods, the exchange rate is viewed as adjusting to equilibrate international trade in financial assets. Because goods price adjust slowly relative to financial asset prices and financial assets are traded continuously each business day and the shift in emphasis from goods market to asset market has important implication. Exchange rates will change every day or even every minute as supplies and demands for financial assets of different nations change. An implication of the asset approach is that exchange rate should be much more variable than goods' prices (Ugwuja, 2017). This seems to be empirical facts. For example, if mean of absolute changes in price and exchange rate of countries are taken, we then look at the average absolute change because exchange rate could be very volatile (Husted and Melvin, 1993).

As recorded by Husted and Melvin (1993), within the family of asset-approach models, there are two basic groups: the monetary approach and the portfolio-balance approach. The monetary approach argues that exchange rate for any two currencies are determined by relative money demand and supply between the two countries. Those relative supplies of domestic and foreign bonds are unimportant. The portfolio balance approach allows relative bonds supplies and demands as well as relative money market conditions to determine the exchange rate (Ugwuja, 2017). The essential difference is that monetary approach (MA) models assume domestic and foreign bonds to be perfect substitutes, whereas portfolio balance (PB) models assume imperfect substitutability.

\subsection{Foreign Exchange Market}

The foreign exchange market as already highlighted is the market designed for purchasing, selling, as well determination of rate of conversion of foreign exchange. In the words of Ibrahim, Long, Ghani and Salleh (2011), the foreign exchange market refers to the organizational setting within which individuals, businesses, governments, and banks buy and sell foreign currencies and other debt instruments. Only a small fraction of daily transactions in foreign exchange actually involve trading of currency. There are various reasons for foreign exchange transactions; such as lubrication of international trade, tourism, foreign investment, and even for speculation. As a result, three operators are identified in the foreign exchange market to include; the dealers, the brokers and the central banks. The dealers are the respective banking institutions licensed to operate on behalf of their customers, who may be private individuals or corporate bodies. The dealers act to meet the purchasing or selling needs of their customers. In Nigeria, they provide facilities for the operation of foreign currency domiciliary accounts. The brokers on their own are the intermediaries between banks. In situation the stock of foreign exchange with dealers in the exchange market rises over or falls below desired level, and the banks intend to sell or purchase currency, the brokers will mediate to facilitate such transactions either among banks or betweens and other economic units. The central banks as the apex banks acts to maintain monitor and manage the exchange rate of the nation's currency and to generally supervise and control the foreign exchange market. In Nigeria, the CBN not only serves these functions but also constitutes an active dealer and participant in the market (Ezirim, 2005; Ejem and Jombo, 2011).

\subsubsection{Foreign Exchange Market Transactions}

There are basically two types of foreign exchange markets; the spot market and the forward exchange market. The spot market is a market that provides facilities for dealings in spot transactions. The spot market is where currencies are traded for current delivery. That means the currencies traded therein are for immediate delivery 
and are immediately delivered to buyers within one or two days. The type of rate of exchange that prevails in this market is known as spot rate. Spot rate is usually expressed in terms of a domestic currency and purchased for immediate delivery of a specified type of foreign exchange. With spot rates, the delivery of the foreign exchange takes place immediately after the completion of the contract. It is the ruling rate at a particular day. Normally, in every bank in Nigeria, the spot rates of exchange are displayed in the banking hall daily as required and stipulated by the regulatory and supervisory authorities. In exercising this, two rates are quoted; buying rate and selling rate. The difference between the buying and selling rates is the banks' spread or margin, constituting banks' profit (Husted and Melvin, 1993; Ejem and Jombo, 2011). The forward market provides facilities for the purchasing and selling of foreign currencies for future delivery. Here a forward transaction implies forward exchange contract requiring the delivery of foreign exchange that is traded upon, to be made at a determined future date. The rate of exchange at which foreign currencies are traded upon in the forward market is called forward rate (Ezirim, 2005). Forward rate is an immediate, firm and binding contract between the buyer and seller of a stated foreign currency, at a rate of exchange fixed at the time of making the contract, for performance by delivery and payment at future date agreed upon when making the contract. A forward rate of exchange is quoted in terms of a margin against the spot rate. This margin could be used in various forms; a premium, in which case the currency for delivery is more expensive than the currency for immediate (spot rate) and a discount, in which case the currency for future is cheaper than the spot rate of the currency. The forward contract can be fixed or option. By fixed forward, implies that the contracting parties agree to the performance of the contract on a specified date in the future, whereas option forward is where the contracting party (the customer) has option to call for performance of the contract at any date from contract date to a specific date in the future, otherwise, any such date between two dates both in the future (Ezirim, 2005; Ejem and Jombo, 2011).

\subsubsection{Foreign Exchange Market Volatility}

Foreign exchange market cannot exist without possibility of risk or volatility. It is these risk or fluctuation expectations that attract charge in form of a spread between the bid and ask prices of currencies. The risk inherent in the foreign exchange dealings is a result of the fact that the exchange rates of the various currencies in terms of others currencies fluctuates due to the economic and political vagrants of the reporting countries. However, foreign exchange risk is seen as the risk where currency of a nation in which the economic unit operates will decline in value relative to the other nation or that its convertibility with other major international currencies, such the USA dollar, will be restricted. Exchange risk can also be seen as uncertainty relating to fluctuations in the rate at which a nation's currency can be exchanged for another in the future (Van-Horne, 2002; Ezirim, 2005). Exchange rate has recently become more volatile since the abandonment of fixed exchange rates in 1971; hence resulting in unquantifiable volume in exchange rate transaction. Foreign exchange transactions have grown geometrically faster than international trade and international investments flows of capital. The risk inherent in exchange transactions among nations at the foreign exchange market has gone up as noticed by the speculators in the market. These resulted in devising several protection measures to insulate or immunize against risk by the speculators in the foreign exchange market (Salvatore, 2004; Backman, 2006).

Exchange rates seem to be very volatile mostly in the short run, as such very responsive to monetary and fiscal policies, politics, changes in expectations and other exogenous factors. In the long run, these exchange rates are determined by the relative prices in various countries, though exchange rate is more volatile than the fundamental variables which determine the exchange rate in the long run (Gartner, 1993; Samuelson and Nordhaus, 2001; Backman, 2006; Ugwuja, 2017). As recorded by Jones and Kanem (1990), exchange rate volatility is influenced by plethora of macro variables, example are demand and supply for goods services, investment, inflation rates in different countries, different growth, and changes in relative rates of return and other factors. Jones and Kanem further argued that volatility can arise from 'overshooting behavior as earlier recorded in this study; which happens when current spot rate does not equal a measure of the long run equilibrium calculated from a long run model. If such behavior arises as a result of the inefficiency of the financial market high exchange rate volatility does not have to imply high transaction costs. Jones and Kenen suggested that, it would only be efficient for the exchange rate to be highly volatile if the underlying economic variables are equally volatile. Otherwise abnormal profit will be presented for speculators in order to smooth exchange rate movement. That is there will be abnormal profit opportunities for the speculators in the exchange market that will smooth exchange rate movement. The exchange rate normally cannot accommodate any pattern or signals about future rates, since it could be used to make a profit (Backman, 2006; Ugwuja, 2017).

\subsubsection{Feature of Market Volatility}

There are basically two features of exchange rate volatility as already noted, that continue to appear in finance literature; volatility persistence and asymmetric effects. Volatility persistence means that unpredictable shocks have long memory and their effects last for many periods ahead. Furthermore, Volatility persistence has to do with how long it takes unpredictable shocks to die out or revert to its long run average. Volatility persistence is of particular interest to investors because it is one of the important determinants of financial asset returns. 
Volatility Persistence has been found to characterize most foreign exchange markets, especially the emerging markets (Adeoye \& Atanda, 2011; Miambo, Marendza \& Sibarda, 2013; Luguterah, Akumbobe \& Yaan, 2015; Ikumariegbe \& Ejem, 2018). The orthodox measure of volatility as represented by variance or standard deviation is unconditional and does not recognize that there are interesting patterns in asset volatility, example, time-varying and clustering properties (Caiado, 2004). Scholars and researchers have introduced various models to explain and predict these patterns in volatility. Engle (1982) introduced the autoregressive conditional heteroskedasticity $(\mathrm{ARCH})$ to model volatility. Engle (1982) modeled the heteroskedasticity by relating the conditional variance of the disturbance in the recent past. Bollerselev (1986) generalized the ARCH model by modeling the conditional variance to depend on its lagged value as well as squared lagged value of disturbance, which is called generalized autoregressive conditional heteroskedasticity (GARCH). The model includes GARCH-in-mean (GARCH-M) model introduced by Engle and Granger (1987) and other models introduced by other researchers.

\subsection{Empirical Literature}

Fama's seminal work publication in 1970 has triggered the test of efficient market theories and stock prices especially in the developed countries. It has been recently observed on the increase scholarly articles on the test of weak efficiency using different econometric techniques also in the developed nations. For instance, applying traditional unit root test; Augmented Dickey Fuller (ADF) and of Phillips-Perron (PP) Wickremasinghe (2004) investigated the weak and semi-strong forms of the efficient market hypothesis (EMH) using the currency of Sri Lanka as a starting point for six international currencies. The study was also subjected to Johansen's tests, Granger causality and Variance Decomposition with monthly spot rates of the Japanese Yen, the Pound sterling, the US dollar, the French Franc, the Indian Rupee and the German Mark, relative to the Sri Lankan Rupee, for the period of January 1986 until November 2000. The study mainly showed evidence of rejecting the semistrong version of the EMH. Also, Ibrahim, Long, Ghani and Salleh (2011) examined the weak-form efficiency of the foreign exchange market in thirty (30) Organizations for Economic Cooperation and Development (OECD) countries using Augmented Dickey-Fuller (ADF), Philip-Perron (PP) and Kwiatkowski-Phillips-Schmidt-Shin analysis to examine for the unit root. The study employed weekly data for the period 2000 to 2007 . The results revealed that weak-form efficiency using ADF and PP tests indicate that the exchange rates under study follow random walks. The current value of the exchange rate cannot be predicted using its past values. Besides, the OECD foreign exchange market is consistent with the weak-form of the Efficient Market Hypothesis. In Africa, Mabakeng and Sheefeni (2014) employed the traditional unit root tests, the Augmented Dickey Fuller, Phillips Perron and Kwiatkowski-Phillips Schmidt-Shin examined the weak form efficiency of the foreign exchange market in Namibia with three bilateral exchange rates using the monthly data for the period spanning from 1993 to 2011. The results of the analysis revealed that there exists weak form efficiency n Namibia's foreign exchange market. The result of Mabakeng and Sheefeni (2014) shows that the past values of exchange rates in Namibia cannot be used to predict the current values. Harish and Sathyanarayana (2016) employed regression technique, normality test, autocorrelation, ADF test, PP test and Run test and more significantly Variance ratio test to examine the random walk hypothesis and the presence of day of the week effect in the Indian forex market for a period of five years from 01-04-2009 to 31-03-2014 taking the daily RBI reference rates of INR/USD. The results of the study showed that forex market is weak form inefficient in the short run and weak form efficient in the long run. It was observed that there is Tuesday and Thursday effect in the forex market. The paper suggests signs of market inefficiency even in the weak form.

\section{Materials and Method}

This study made use of data obtained from the CBN for exchange rates between the Nigerian Naira and US Dollar from January 02, 2001 to August 09, 2020 (4847 observations). The choice of exchange rate between the Nigerian Naira and US Dollar, is that the US Dollar is today the dominant vehicle currency, serving as unit of account, medium of exchange and store of value not only for domestic transactions in USA but also for private and official international transactions. The U.S. Dollars replaced the British pound sterling after World War II (WW II) as the dominant vehicle currency because of its more stable value, the existence of large and well developed financial markets in the USA and the very large size of the USA economy. Though the USA has gradually lost its position as sole vehicle currency that it had at the end of WW II, it remains by far the dominant vehicle currency in Nigeria and in the world today. As a result, the USA derives reasonable benefit from the dollar being used as a vehicle currency known as seignorage and it amounts to an interest free loan from foreigners to USA on the amounts of dollars held abroad (Salvatore, 1995; Ejem and Jombo, 2011).

On the tools for the analysis, Augumented Dickey Fuller (ADF) unit root test, Pairwise Granger Causality test, Regression test, Normality/Random Walk test, ARCH-GARCH Model, the Autocorrelation cum partial autocorrelation method and Variance Ratio Test are employed to test weak form efficiency of the foreign exchange market in Nigeria or to know whether the foreign exchange market in Nigeria follows a random walk. 
The Exponential Generalized Autoregressive Conditional Heteroscedasticity (EGARCH) framework is used to test the volatility of foreign exchange market in Nigeria. The choice of EGARCH framework is to accommodate examination of conditional variance (volatility), asymmetric effect and volatility persistence (Nelson, 1991). Also the ARCH test to check if model is heteroskedastic

\section{Results and Interpretations}

\subsection{Trend Analysis}

A close look at figure 1 below shows the presence of fluctuations or volatility in exchange rate in Nigeria. This confirms ARCH effects in the model and validated the choice of EGARCH framework as part of the model estimation techniques.

$\%$ Change USD/Naira

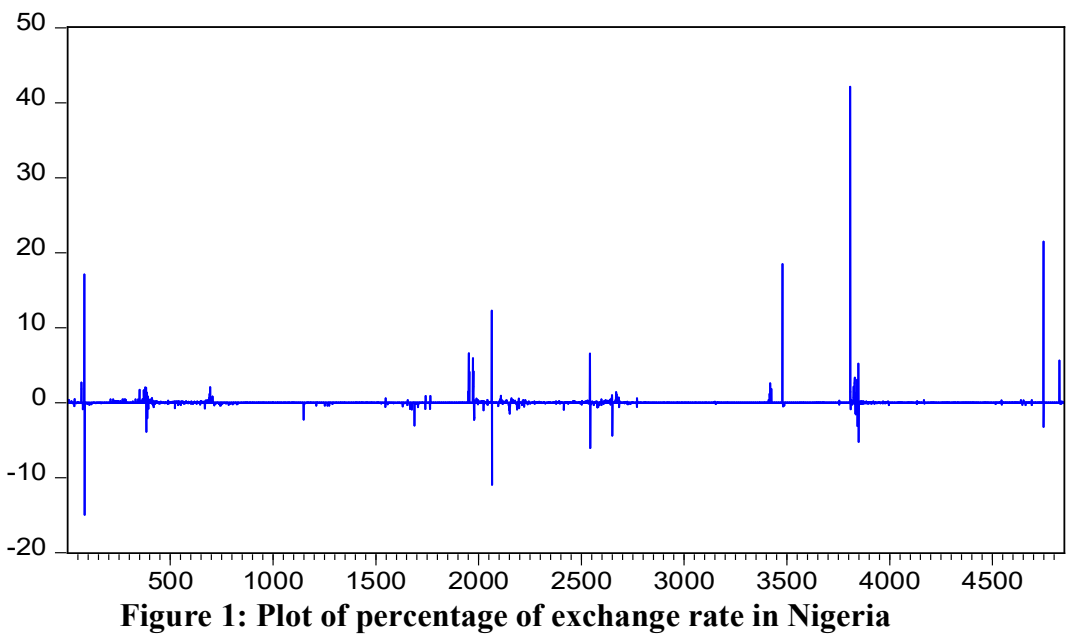

\subsection{Descriptive Statistics}

Table 1 below summarized the distribution of exchange rate (USD/Naira) in Nigeria. The table revealed that USD/Naira parades Jarque-Bera coefficient of 1169.276 with probability value of 0.000000 suggesting an abnormal distribution. The third moment (Kurtosis) is 2.867636 , which is lower than 3 indicating platykurtic distributions. This suggests that small shocks of either sign are likely to present itself with exchange rate volatility in Nigeria. The skewness is 1.201267 , which is a positive coefficient. It is important to point out that the skewness is positively skewed suggesting the distribution has a long right tail.

Table 1: Descriptive Statistics USD/Naira

\begin{tabular}{|l|c|c|}
\hline & USD/NAIRA & USD/NAIRA \\
\hline Mean & 178.5816 & 178.5447 \\
\hline Median & 150.0000 & 150.0000 \\
\hline Maximum & 381.3000 & 381.3000 \\
\hline Minimum & 110.0000 & 0.000000 \\
\hline Std. Dev. & 72.73060 & 72.76831 \\
\hline Skewness & 1.201267 & 1.197622 \\
\hline Kurtosis & 2.867636 & 2.871014 \\
\hline Jarque-Bera & 1169.276 & 1162.274 \\
\hline Probability & 0.000000 & 0.000000 \\
\hline Sum & 865584.8 & 865584.8 \\
\hline Sum Sq. Dev. & 25634078 & 25665963 \\
\hline Observations & 4847 & 4848 \\
\hline
\end{tabular}

Authors' computation output using E-view 10. 


\subsection{Unit Root Test of USD/Naira}

Table 2 shows the results of unit test for daily USD/Naira. The results revealed that USD/Naira is not stationary at level, but are integrated at order one or differenced once to be stationary at all significant levels. Having established that USD/Naira is not stationary at level but integrated at order one to be stationary. Therefore the researchers have enough evidence to announce that the Nigeria foreign exchange market does not follow a random walk using unit test. Though not satisfied at this stage, because researchers, such as Liu and He (1991) argued that the unit root tests may not detect departures from a random work; one has to be cautious of this result. In view of this, the researchers resorted to using the Pairwise Granger Causality test, Regression test, Normality/Random Walk test, ARCH-GARCH Model, the Autocorrelation cum partial autocorrelation test and Variance Ratio Test, to further authenticate the already found result.

Table 2: Unit root at Level

\section{At Level}

Null Hypothesis: USD_NAIRA has a unit root

Lag Length: 1 (Automatic - based on SIC, maxlag=31)

\begin{tabular}{|l|c|c|c|c|}
\hline & & t-Statistic & Prob. $^{*}$ \\
\hline Augmented Dickey-Fuller test statistic & $1 \%$ level & & 1.398640 & 0.9991 \\
\hline Test critical values: & $1 \% \%$ level & & -3.431518 & \\
\hline & $5 \%$ level & & -2.861941 & \\
\hline & $10 \%$ & -2.567026 & \\
\hline
\end{tabular}

\section{At First Difference}

Null Hypothesis: D(USD NAIRA) has a unit root

Lag Length: 0 (Automatic - based on SIC, maxlag=31)

\begin{tabular}{|l|c|c|c|c|}
\hline \multicolumn{2}{|l|}{$\mid$} & & t-Statistic & Prob. $^{*}$ \\
\hline Augmented Dickey-Fuller test statistic & -76.61110 & 0.0001 \\
\hline Test critical values: & $1 \%$ level & & -3.431518 & \\
\hline & $5 \%$ level & & -2.861941 & \\
\hline & $10 \%$ level & & -2.567026 & \\
\hline
\end{tabular}

Authors' computation output using E-view 10.

\subsection{Causality Test}

This is useful for testing the short run direction of causality among variables. Pairwise Granger Causality test is used as revealed in table 3 below.

Granger Causality test in table 3 for daily USD/Naira revealed that daily USD/Naira and USD/Naira at lag 1 have bidirectional causality, suggestion of null hypothesis. This is another evidence to show that Nigerian foreign exchange is weak form inefficient.

Table 3: Pairwise Granger Causality Tests

\begin{tabular}{|l|c|c|c|}
\hline Null Hypothesis: & Obs & F-Statistic & Prob. \\
\hline USD_NAIRA_1_does not Granger Cause USD_NAIRA & 4846 & 25.8508 & $4 . \mathrm{E}-07$ \\
\hline USD_NAIRA does not Granger Cause USD_NAIRA_1_ & & $2.7 \mathrm{E}+26$ & 0.0000 \\
\hline
\end{tabular}

\section{Authors' computation output using E-view 10}

\subsection{Regression Analysis}

Then the researchers moved to check the relationship between the USD/Naira and USD/Naira at lag 1 using Ordinary Least Square (OLS) Model as shown below in table 4. Table 4 below shows Ordinary Least Square Regression result. It reveals a significant relationship between USD/Naira and USD/Naira at lag 1. That implies that past exchange rates can be used to predict current and future exchange rates, thereby confirming weak form inefficiency of the Nigerian foreign exchange market. 
Table 4: Ordinary Least Square Regression

Dependent Variable: USD_NAIRA
\begin{tabular}{|l|r|r|r|r|}
\hline \multicolumn{4}{|l|}{ Method: Least Squares } \\
\hline \multicolumn{1}{|l|}{ Variable } & Coefficient & Std. Error & t-Statistic & Prob. \\
\hline USD NAIRA 1 & 0.999634 & 0.000475 & 2105.386 & 0.0000 \\
\hline C & 0.144062 & 0.091514 & 1.574206 & 0.1155 \\
\hline R-squared & 0.998908 & Mean dependent var & 178.5816 \\
\hline Adjusted R-squared & 0.998908 & S.D. dependent var & 72.73060 \\
\hline S.E. of regression & 2.403477 & Akaike info criterion & 4.592123 \\
\hline Sum squared resid & 27988.12 & Schwarz criterion & 4.594799 \\
\hline Log likelihood & -11127.01 & Hannan-Quinn criter. & 4.593062 \\
\hline F-statistic & 4432648. & Durbin-Watson stat & 1.676630 \\
\hline Prob(F-statistic) & 0.000000 & & & \\
\hline
\end{tabular}

Authors' computation output using E-view 10.

\subsection{Normality Test}

The researchers then proceeded to distribution/randomness of exchange rate series as shown below in table 5 . From table 5 below, the first moment or mean (average annual rate) is 0.612317 and the second moment (standard deviation) has value of 15.50166 , which signposts relatively significant risk level in the Nigeria foreign exchange market. The maximum value is 768.3206 and minimum -34.40124 , a clear evidence of high variability of exchange rate changes in the Nigeria foreign exchange market. Finally, Jarque-Bera has probability value of 0.000000 , which is highly significant, suggesting abnormal distribution. This abnormal distribution is evidence validating weak form inefficiency.

Table 5: Normality Test

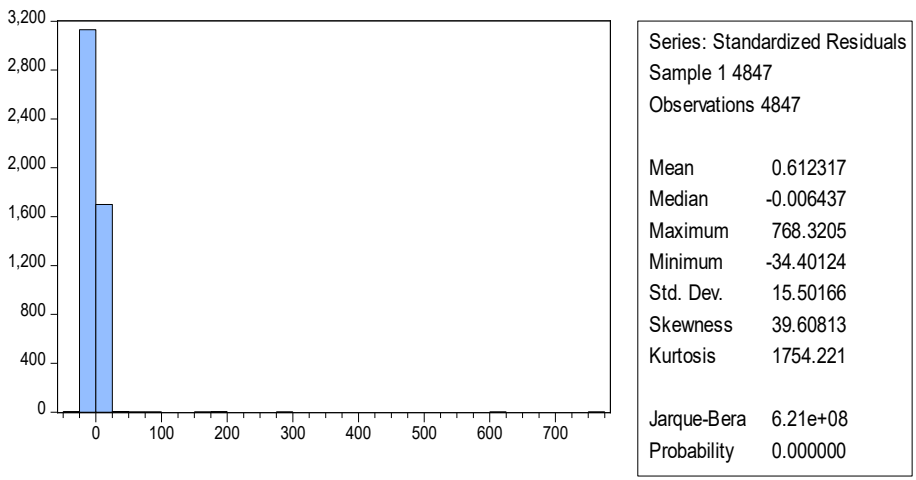

Authors' computation output using E-view 10.

\subsection{ARCH-GARCH Test}

The ARCH-GARCH developed by Engle in 1982 and used to capture the effect of serial correlation of volatility in time series data. It expresses conditional variance as distributed lag of past squared. This is shown below in table 6.

The estimated standard GARCH $(1,1)$ Model presented in table 6 below shows that the ARCH term and GARCH term are significant. That means that the conditional means and the lagged rate parameters in both of the mean equations are significantly different from zero. The error terms of the mean equations are not independently and identically distributed (iid) thereby indicating Nigerian foreign exchange market does not follow random walk. 
Table 6: ARCH-GARCH Test

\begin{tabular}{|c|c|c|c|c|}
\hline \multicolumn{5}{|c|}{ Dependent Variable: USD_NAIRA } \\
\hline \multicolumn{5}{|c|}{$\begin{array}{l}\text { Method: ML ARCH - Generalized error distribution (GED) (BFGS / Marquardt } \\
\text { steps) }\end{array}$} \\
\hline \multicolumn{5}{|c|}{$\mathrm{GARCH}=\mathrm{C}(3)+\mathrm{C}(4) * \mathrm{RESID}(-1)^{\wedge} 2+\mathrm{C}(5) * \mathrm{GARCH}(-1)$} \\
\hline Variable & Coefficient & Std. Error & z-Statistic & Prob. \\
\hline USD_NAIRA_ 1 & 0.999819 & $2.40 \mathrm{E}-06$ & 416375.7 & 0.0000 \\
\hline \multirow[t]{2}{*}{$\mathrm{C}$} & 0.028217 & $1.25 \mathrm{E}-05$ & 2251.302 & 0.0000 \\
\hline & \multicolumn{2}{|c|}{\begin{tabular}{l|l} 
Variance Equation & \\
\end{tabular}} & & \\
\hline $\mathrm{C}$ & 0.009422 & 0.000687 & 13.72249 & 0.0000 \\
\hline $\operatorname{RESID}(-1)^{\wedge} 2$ & 0.134737 & 0.025376 & 5.309643 & 0.0000 \\
\hline GARCH(-1) & 0.192177 & 0.028960 & 6.635913 & 0.0000 \\
\hline GED PARAMETER & 0.247796 & 0.003166 & 78.26543 & 0.0000 \\
\hline R-squared & 0.998907 & \multicolumn{2}{|c|}{ Mean dependent var } & 178.5816 \\
\hline Adjusted R-squared & 0.998907 & \multicolumn{2}{|c|}{ S.D. dependent var } & 72.73060 \\
\hline S.E. of regression & 2.404937 & \multicolumn{2}{|c|}{ Akaike info criterion } & -3.974874 \\
\hline Sum squared resid & 28022.14 & \multicolumn{2}{|c|}{ Schwarz criterion } & -3.966845 \\
\hline Log likelihood & 9639.107 & \multicolumn{2}{|c|}{ Hannan-Quinn criter. } & -3.972056 \\
\hline Durbin-Watson stat & 1.674986 & & & \\
\hline
\end{tabular}

Authors' computation output using E-view 10.

\subsection{Autocorrelation and partial Autocorrelation tests}

As already stated, Autocorrelation test, added to others tools in this study are for more authentications. Autocorrelation test which is a special correlation test that examines the relationship between successive values of the same variable and not necessarily between two or more variables. The test is shown in table 7 below showing autocorrelation test for daily exchange rate (USD/Naira). It revealed that the individual autocorrelation (AC) at different lags from 1-36 and the associated probability values suggest that successive autocorrelation of the rates are significant from 1-36 for daily USD/Naira. This is sufficient evidence suggesting that there is existence of volatility clustering in the rate series and that the Nigerian foreign exchange market do not follow random walk.

Table 7 Autocorrelation Test for USD/NAIRA

\begin{tabular}{|c|c|c|c|c|c|c|}
\hline Autocorrelation & Partial Correlation & & $\mathrm{AC}$ & PAC & Q-Stat & Prob \\
\hline$* * * * * * *$ & $* * * * * * *$ & 1 & 0.999 & 0.999 & 4838.3 & 0.000 \\
\hline$* * * * * * *$ & & 2 & 0.998 & 0.024 & 9666.6 & 0.000 \\
\hline$* * * * * * *$ & & 3 & 0.997 & 0.002 & 14485 . & 0.000 \\
\hline |******* & & 4 & 0.995 & -0.002 & 19293. & 0.000 \\
\hline$* * * * * * *$ & & 5 & 0.994 & 0.001 & 24091. & 0.000 \\
\hline$* * * * * * *$ & & 6 & 0.993 & -0.000 & 28879 . & 0.000 \\
\hline |******* & & 7 & 0.992 & -0.006 & 33657. & 0.000 \\
\hline |******* & & 8 & 0.991 & 0.001 & 38425 . & 0.000 \\
\hline$* * * * * * *$ & & 9 & 0.990 & -0.002 & 43183. & 0.000 \\
\hline$* * * * * * *$ & & 10 & 0.988 & 0.001 & 47931. & 0.000 \\
\hline |******* & & 11 & 0.987 & -0.000 & 52669. & 0.000 \\
\hline$* * * * * * *$ & & 12 & 0.986 & -0.000 & 57397. & 0.000 \\
\hline$* * * * * * *$ & & 13 & 0.985 & -0.002 & 62115 & 0.000 \\
\hline$* * * * * * *$ & & 14 & 0.984 & -0.002 & 66822 & 0.000 \\
\hline$* * * * * * *$ & & 15 & 0.983 & 0.001 & 71520 . & 0.000 \\
\hline |******** & & 16 & 0.982 & -0.001 & 76208 . & 0.000 \\
\hline$* * * * * * *$ & & 17 & 0.980 & -0.009 & 80885 . & 0.000 \\
\hline$* * * * * * *$ & & 18 & 0.979 & -0.006 & 85552. & 0.000 \\
\hline |******** & & 19 & 0.978 & -0.005 & 90209. & 0.000 \\
\hline |******** & & 20 & 0.977 & -0.000 & 94856. & 0.000 \\
\hline |******** & & 21 & 0.976 & 0.002 & 99492. & 0.000 \\
\hline$* * * * * * *$ & & 22 & 0.974 & -0.011 & 104118 & 0.000 \\
\hline$* * * * * * *$ & & 23 & 0.973 & 0.051 & 108734 & 0.000 \\
\hline |******** & & 24 & 0.972 & -0.002 & 113342 & 0.000 \\
\hline
\end{tabular}




\begin{tabular}{|c|c|c|c|c|c|}
\hline ********* & 25 & 0.971 & -0.006 & 117939 & 0.000 \\
\hline$* * * * * * *$ & 26 & 0.970 & 0.006 & 122527 & 0.000 \\
\hline$* * * * * * *$ & 27 & 0.969 & -0.002 & 127106 & 0.000 \\
\hline |******** & 28 & 0.968 & -0.003 & 131676 & 0.000 \\
\hline$* * * * * * *$ & 29 & 0.967 & 0.005 & 136236 & 0.000 \\
\hline$* * * * * * *$ & 30 & 0.966 & 0.001 & 140787 & 0.000 \\
\hline$* * * * * * *$ & 31 & 0.965 & -0.000 & 145329 & 0.000 \\
\hline$* * * * * * *$ & 32 & 0.964 & -0.002 & 149862 & 0.000 \\
\hline$* * * * * * *$ & 33 & 0.963 & -0.001 & 154385 & 0.000 \\
\hline |******** & 34 & 0.961 & -0.000 & 158899 & 0.000 \\
\hline$* * * * * * *$ & 35 & 0.960 & -0.013 & 163404 & 0.000 \\
\hline$* * * * * * *$ & 36 & 0.959 & 0.012 & 167899 & 0.000 \\
\hline
\end{tabular}

\subsection{Variance Ratio Test}

The variance ratio technique tests the null hypothesis that a given time series is independent and identically distributed, thereby if a series follows a random work with uncorrelated changes in the series, say (pt), then the variance of its q-differences would be q times the variance of its first differences (Ogbulu, 2016).

The result of variance ratio test in table 8 below reveals as follows; both the individual (2-16) and joint tests show all lags are significant, suggesting rejection of the null hypothesis for all lags. This is sufficient evidence that the Nigerian foreign exchange market does not follow random walk, hence weak form inefficient.

\section{Table 8 Variance Ratio Test on USD/Naira}

Null Hypothesis: USD_NAIRA is a random walk

Standard error estimates assume no heteroscedasticity

Lags specified as grid: $\min =2, \max =16$, step $=1$

\begin{tabular}{|c|c|c|c|c|}
\hline \multicolumn{2}{|c|}{ Joint Tests } & Value & df & Probability \\
\hline \multicolumn{2}{|c|}{$\operatorname{Max}|z|($ at period 2)* } & 6.596338 & 4846 & 0.0000 \\
\hline \multicolumn{2}{|c|}{ Wald (Chi-Square) } & 47.07743 & 15 & 0.0000 \\
\hline \multicolumn{5}{|c|}{ Individual Tests } \\
\hline Period & Var. Ratio & Std. Error & z-Statistic & Probability \\
\hline 2 & 0.905243 & 0.014365 & -6.596338 & 0.0000 \\
\hline 3 & 0.868951 & 0.021414 & -6.119743 & 0.0000 \\
\hline 4 & 0.852747 & 0.026875 & -5.479248 & 0.0000 \\
\hline 5 & 0.842577 & 0.031472 & -5.001950 & 0.0000 \\
\hline 6 & 0.836323 & 0.035511 & -4.609138 & 0.0000 \\
\hline 7 & 0.837620 & 0.039153 & -4.147371 & 0.0000 \\
\hline 8 & 0.836863 & 0.042493 & -3.839187 & 0.0001 \\
\hline 9 & 0.836875 & 0.045594 & -3.577753 & 0.0003 \\
\hline 10 & 0.835534 & 0.048502 & -3.390900 & 0.0007 \\
\hline 11 & 0.835298 & 0.051248 & -3.213833 & 0.0013 \\
\hline 12 & 0.834866 & 0.053856 & -3.066225 & 0.0022 \\
\hline 13 & 0.834569 & 0.056345 & -2.936059 & 0.0033 \\
\hline 14 & 0.835750 & 0.058729 & -2.796743 & 0.0052 \\
\hline 15 & 0.836927 & 0.061021 & -2.672407 & 0.0075 \\
\hline 16 & 0.837242 & 0.063231 & -2.574024 & 0.0101 \\
\hline
\end{tabular}

\subsection{Estimation of Model using EGARCH}

The EGARCH-in-mean model is an improvement of the GARCH. Improvement of the GARCH imposes a nonnegativity constant on market variable, and permits for conditional variance to respond asymmetrically to returns innovations of different signs. If $\gamma$ is negative, leverage effect exists. Implying that, bad news increases predictable volatility more than good news of similar magnitude (Black, 1976; Christie, A.A. (1982). In other words, negative value of $\gamma$ is called the 'sign effect'. If $\propto$ is positive, then the conditional volatility tends to rise (fall) when the absolute value of the standardized residuals is larger (smaller). ${ }^{\alpha}$ is called the 'magnitude effect'. The model for volatility using EGARCH framework is specified as follows:

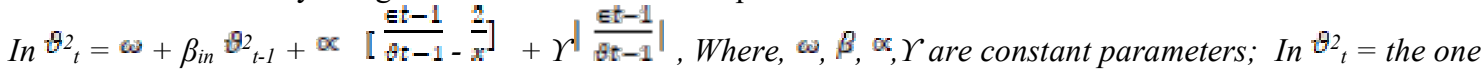
period ahead volatility forecast; $\omega=$ the mean level, $\beta=$ persistence parameter $\propto=$ volatility clustering coefficient, In ${ }^{\vartheta 2}{ }_{t-1}=$ the past variance, $\gamma=$ the leverage effect. 
Table 9 below shows as follows; the coefficient and probability of the conditional volatility $\left(\mathrm{b}_{2}\right)$ shows that conditional volatility is negatively and significantly related to exchange rate, implying that volatility exacts negative impact on Nigerian foreign exchange market. This contradicts the theory that predicts a positive relation between expected returns and volatility if investors are risk averse (Ejem, Ogbonna and Ezirim, 2018). The persistence parameter $(\beta)$, persistent coefficient $\left(\alpha_{1}+\beta_{1}\right)$ is very close to 1 , enough evidence to state that exchange rate volatility between the US Dollar and Naira is persistent. The leverage effect $(\Upsilon)$ has positive coefficient and significant probability value. This contradicts the rule of thumb; If $\gamma$ is negative, leverage effect exists. That is bad news increases predictable volatility more than good news of similar magnitude. This shows that there is no asymmetric effect in the Nigerian foreign exchange market. Magnitude effect $\left({ }^{\complement}\right)$ (volatility clustering) has positive coefficient with significant probability value. That means the conditional volatility will not rise or fall when the absolute value of the standardized residual is larger (smaller).

All these unpredictable stances of the EGARCH framework in table 9 show that Nigerian foreign exchange market is weak form inefficient.

Table 9 EGARCH Test

\begin{tabular}{|c|c|c|c|c|}
\hline \multicolumn{5}{|c|}{ Dependent Variable: USD NAIRA } \\
\hline \multicolumn{5}{|c|}{ Method: ML ARCH - Student's t distribution (BFGS / Marquardt steps) } \\
\hline \multicolumn{5}{|c|}{$\mathrm{LOG}(\mathrm{GARCH})=\mathrm{C}(4)+\mathrm{C}(5) * \mathrm{ABS}(\operatorname{RESID}(-1) / @ \mathrm{SQRT}(\mathrm{GARCH}(-1)))+\mathrm{C}(6)$} \\
\hline \multicolumn{5}{|c|}{\begin{tabular}{|l|l|}
$*$ RESID(-1)/@SQRT(GARCH(-1)) + C(7)*LOG(GARCH(-1)) \\
\end{tabular}} \\
\hline Variable & Coefficient & Std. Error & z-Statistic & Prob. \\
\hline GARCH $\left(b_{2}\right)$ & -0.780064 & 0.245162 & -3.181834 & 0.0015 \\
\hline USD_NAIRA_1_ $\left(b_{1}\right)$ & 0.999999 & $1.58 \mathrm{E}-06$ & 634310.1 & 0.0000 \\
\hline \multirow[t]{2}{*}{$\mathrm{C}\left(\mathrm{b}_{0}\right)$} & 0.142875 & 0.027914 & 5.118484 & 0.0000 \\
\hline & \multicolumn{2}{|c|}{ Variance Equation } & & \\
\hline$C(4)\left({ }^{\infty}\right)$ & -1.713382 & 0.260003 & -6.589846 & 0.0000 \\
\hline$C(5)(\infty)$ & -0.026791 & 0.006423 & -4.171372 & 0.0000 \\
\hline $\mathrm{C}(6)(\Upsilon)$ & 0.026785 & 0.006434 & 4.162968 & 0.0000 \\
\hline $\mathrm{C}(7)(\beta)$ & -0.009623 & 0.002513 & -3.829777 & 0.0001 \\
\hline \begin{tabular}{|c|} 
T-DIST. DOF \\
\end{tabular} & 2.000008 & $1.82 \mathrm{E}-05$ & 109769.8 & 0.0000 \\
\hline R-squared & 0.998907 & \multicolumn{2}{|c|}{ Mean dependent var } & 178.5816 \\
\hline Adjusted R-squared & 0.998907 & \multicolumn{2}{|c|}{ S.D. dependent var } & 72.73060 \\
\hline S.E. of regression & 2.405039 & \multicolumn{2}{|c|}{ Akaike info criterion } & -5.071292 \\
\hline Sum squared resid & 28018.73 & \multicolumn{2}{|c|}{ Schwarz criterion } & -5.060587 \\
\hline Log likelihood & 12298.28 & \multicolumn{2}{|c|}{ Hannan-Quinn criter. } & -5.067534 \\
\hline Durbin-Watson stat & 1.674466 & & & \\
\hline
\end{tabular}

\subsection{Heteroscedasticity Test}

Table 10 below shows that F-statistic has coefficient of 0.001567 with probability value of 0.9684 , suggesting no rejection of null hypothesis. This is enough evidence that show no presence of heteroscedasticity in the model, hence the model is homoscedastic.

Table 10: Heteroscedasticity Test: ARCH

\begin{tabular}{|l|l|l|r|}
\hline F-statistic & 0.001567 & Prob. F(1,4844) & 0.9684 \\
\hline Obs*R-squared & 0.001567 & Prob. Chi-Square(1) & 0.9684 \\
\hline
\end{tabular}

\section{Concluding Remarks and Recommendations}

This study, test of weak form efficiency and volatility of the Nigerian foreign exchange market using parametric tools stated in study revealed that, the Nigerian foreign exchange market is not weak form efficient, corroborating Ibrahim, Long, Ghani and Salleh (2011) and Harish and Sathyanarayana (2016). One important revelation in this study is the Nigerian foreign exchange market does not follow the theory that predicts a positive relation between expected returns and volatility if investors are risk averse. No wonder the exchange rate business in Nigeria is very lucrative. The dealers always make abnormal profit at every slightest opportunity. All credit to the non compliance of random walk of the Nigerian foreign exchange market. That means the speculators or risk takers in the market will always make abnormal profits at the expense of the risk averse. Again, it was also discovered that the Nigerian foreign exchange market volatility is persistent despite all efforts to stimulate exports and counteract the fluctuations therein the market. Consequent upon the findings, the researchers suggest that the regulatory authorities of the Nigerian foreign exchange market tighten up their belt to enhancing the efficiency of the market. Again, the authority must do everything to stabilize the naira to ensure efficiency in the foreign market in Nigeria. 
References

Adeoye, B.W., \& Atanda, A.A. (2011). Exchange rate volatility in Nigeria: Consistency, persistency \& severity analysis. CBN Journal of Applied Statistics, 2(2), 29-49.

Bachellier, L. (1900). Theorie de la Paris: Gauthier - Villars. Reprinted in English (Bones trans.) in Cootner PH edited 1964". The random character of stock market prices, MITpress.

Backman, M. (2006). Exchange rate volatility: How the Swedish Export is influenced. Jonkoping International Business School.

Bauwens, L, \& Sucarat, G. (2005). General to specific modeling of exchange rate volatility: A forecast evaluation, 13 December 2005.

Becmann, J. (2013). Non linear exchange rate adjustment and the monetary model. Review of International Economics, 12(4), 654-670.

Bhalla, V.K. (2011). Investment management: Security analysis and portfolio management. New Delhi: S. Chad and Company Ltd.

Black, F. (1976). Studies of stock market volatility changes. Proceedings of the American Statistical Association, Business and economics Section. 177-181.

Black, F. (1976). Studies of stock market volatility changes. Proceedings of the American Statistical Association, Business and economics Section. 177-181.

Bollerslev,T.(1986). Generalized autoregressive conditional heteroscedasticity. Journal of Econometrics. 31:307- 327.

Brealey, R.A. \& Myers, S.C. (2003). Principles of corporate finance. New Delhi: McGraw Hill.

Brooks, C.(2008). Introductory econometrics for finance ( $2^{\text {nd }}$ ed). New York: Cambridge University Press

Broyles, J. (2003). Financial management and real options. England: John Wiley \& Son Ltd.

Caiado, J. (2004). Modeling and forecasting the volatility of the Portuguese stock, IndexPSI-2, Munich Personal Repec Archive (MPRA) Paper No.2304.posted 07.

Christie, A.A. (1982). The stochastic behavior of common stock variance-value, leverage and interest rate effects. Journal of Financial Economics, 10(4), 407-423.

Downey, L. \& Scott, G. (2020). Efficient Market hypothesis. www.investopia.org. Retrieved on 09/04/2020

Ejem, C.A., \& Jombo, C.O. (2011). International finance. Aba: Ker Expert Publisher.

Ejem,C.A., Ogbonna, U.G., \& Ezirim, B.C. (2018). The relationship between stock market return and conditional variance (volatility) in the Nigeria stock market. International Journal of Business and Economic perspective, 13(1), 89-105.

Emenike, K.O. \& Aleke, S.F (2012). Modeling asymmetric volatility in the Nigerian stock exchange. European Journal of Business and Management, 4(12), 52-59.

Engle, R.F. \& Granger, C.J. (1987). Co-integration and error correlation: Representation. estimation and testing. Journal of Econometrics, 55:251-276.

Engle, R.F.(1982). Autoregressive conditional heteroscedasticity with estimates of the variance of U.K. Inflation. Journal Econometrics. 50:987-1008.

Ezirim, C.B. (2005). Finance Dynamics: Principles, techniques and applications ( ${ }^{\text {rd }}$ ed). Portharcourt: Markowitz Centre for Research and Development.

Fama, E. (1965).The behaviour of stock market prices. Journal of Business, 38, January edition, 34-49.

Fama, E.F. (1970). Efficient capital markets: A review of theory and empirical work. Journal of Finance, 25(1), 83-417.

Gartner, M.(1993). Macro economics under flexible exchange rate. UK: Harvester Wheatsheaf.

Harish, S. N., \& Sathyanarayana, S. (2016). Forex market weak form efficiency and seasonality: Evidence from India. Kuwait Chapter of Arabian Journal of Business and Management Review, 6(4), 21-36.

Husted, S., \& Melvin, M. (1993). International Economics (2 ${ }^{\text {nd }}$ ed). New York: Harper Collins College Publications.

Ibrahim, J., Long, Y., Ghani, H.A., \& Salleh, S.I.M. (2011). Weak-form efficiency of foreign exchange market in the Organisation for Economic Cooperation and Development Countries: Unit root test. International Journal of Business and Management, 6(6), 53-65

Ikumariegbe, V.O., \& Ejem, C.A. (2018). Exchange rate volatility shock persistence: A comparative analysis of Nigeria, South Africa and Ghana. Uniport Journal of Business, Accounting and Finance Management, 8(3), 205-2012.

Jones, R.W., \& Kenen, P.B. (1990). Handbook of international economics (Vol.2). Netherlands: Elsevier Science.

Liu, C. and He, J. (1991). A variance - ratio test of random walks in foreign exchange rates. Journal of finance, 46(2),773-785.

Lugutaerah, A., Akumbode, R.A., \& Yaan, E.A. (2015). Modeling exchange rate volatility of the Ghana Cedi to the US Dollar using GARCH. Mathematical Theory and Modeling, 5(8), 92-103. 
Mabakeng, M.E.P., \& Sheefeni, J.P.S. (2014). Examining the weak form efficiency in foreign exchange market in Namibia. International Review of Research in Emerging Markets and the Global Economy (IRREM), 1(4), 174-187

Malkiel (1973). A Random walk down wall street: The Time-Tested strategy for successful investing. New York: W.W Norton and Co.

Miambo, C., Maredza, A., \& Sibanda, K.(2013). Effects of exchange rate volatility on the stock market: A case of South Africa. Mediterranean Journal of Social Sciences, 4(14), 561.

Nelson, D. (1991). Conditional heteroscedasticity in asset returns: a new approach. Journal of Econometrics, $59(2), 347-370$.

Ogbulu, O.M. (2016). Weak-form market efficiency, estimation interval and the Nigerian Stock Exchange: Empirical evidence. International Journal of Economic and Business, 5(1), 84-116.

Okpara G.C. (2012). Volatility modeling and the Nigerian stock return relationship in EGARCH-in-mean framework. International Journal of Current Research, 3(8), 176-185.

Okpara, G.C. (2011). Random walk. Semi-strong hypothesis and market behavior: A test of weak and semistrong form efficiency in the Nigerian stock market. USA: LAP LAMBERT Publishing

Peterson, K ( 1905) The problem of Random Walk. Nature; 72: 294-34.

Pukthuanthan-Le, K \& Thomas, L.R. (2008). Weak form in currency markets. Financial Analyst Journal, 64(3), $31-32,35-52$.

Rayleagh L (1905). A Random walks. Nature, 73: 174

Ross, S.A., Westerfield, R.W., Jaffe, J. \& Jordan, B.D. (2009). Modern financial management ( $8^{\text {th }}$ edition). New Delhi: McGraw Hill.

Salvatore, D. (2004). International Economics ( $8^{\text {th }}$ ed) USA: John Wiley \& Sons

Samulson ,P.A., \& Nordhaus, W.D. (2001). Economics (7th ed). USA: MC Graw-Hill.

Ugwuja, C.O.(2017). Empirical investigation of internal and external shocks on exchange rate volatility in Nigeria. Vertg.https//www.grin.com/document/457704. Retrieved on 19/11/2019.

Van-Horne, J.C. (2002). Financial management and policy. New Jersey: Prentice Hall.

Wickremasinghe, G. B. (2005). Efficiency of foreign exchange markets: A developing country perspective. Asian Academy of Management Journal, 10(1), 1-17. 